\title{
An Interview with 2006-07 ALISE President Connie Van Fleet
}

Correspondence for Reference \& User Services Quarterly should be addressed to Editor Diane Zabel, Schreyer Business Library, The Pennsylvania State University, 309 Paterno Library, University Park, PA 16802; e-mail:dxz2@psu.edu.

Connie Van Fleet is Professor, School of Library and Information Studies, University of Oklahoma, Norman. onnie Van Fleet is well known to RUSQ readers. She edited the journal (in conjunction with Danny P. Wallace) for twelve years. Upon completing her final term as editor, she assumed leadership for the Association for Library and Information Science Education (ALISE). ALISE is the premier organization for faculty teaching in graduate programs in library and information science in North America. Connie graciously took time out of her busy schedule to respond to my questions about library education and LIS students.

All of a sudden librarianship is becoming portrayed as a hot occupation. Last spring, U.S. News \& World Report (see "The Best Careers for 2007," in the issue dated March 19, 2007) ranked librarianship as one of the top twenty-five careers for 2007. This summer, the New York Times (see "A Hipper Crowd of Shushers," in the July 8, 2007 issue) ran a story on how librarianship is becoming a career choice for Generation Xers. Have library schools noticed a marked increase in applications over the last year or two?

I loved those articles and really got quite a kick out of sharing the NYT piece with my students. It's great to see librarianship getting attention and respect. I think those articles, however, reflect recognition of a trend, rather than drive enrollment figures. Enrollment in ALA-accredited programs has been increasing steadily since an inexplicable dip in 1999. In fact, according to the ALISE statistics, enrollment in accredited masters' programs grew by about 8\% per year between 1999 and 2006, resulting in an increase of over 65\%. The 2007 statistics have just been collected from the schools and have not yet been analyzed, but it is my sense that this upward trend is continuing.

Who is attending graduate programs in library and information science these days? Is there a demographic profile of the typical student enrolled in a master's degree program? Is librarianship a second career for many individuals?

There is a very diverse group of individuals who attend graduate programs in library and information science for a variety of reasons. The profession may still be overwhelmingly female and white, but we are seeing more men and ethnic groups represented in the program. I think the data gathered in Fall 2006 probably gives a pretty accurate picture of this year's class. It shows that enrollment in MLIS programs was 71\% female and 29\% male. Of those students for whom ethnicity data is reported (such reporting is illegal in Canada), $74 \%$ of the stu- 
dents were identified as white, with about 4.4\% black, $4.34 \%$ Hispanic, and 3.37\% Asian. Nearly 5\% were international students. Perhaps the most dramatic change is in the age of those attending graduate programs in library and information science: $40 \%$ were under the age of 30; $69 \%$ were under 40 ; and $87 \%$ under 50 years old. The majority $(73.7 \%)$ of students reside in the state or province in which they attend school.

Librarianship still remains a second career for many individuals. We don't have statistics on students who come into our programs with advanced degrees or from other careers, but my experience at three different universities and my impression from speaking with other faculty indicate that a number of students come to us from a variety of professions, including law, music, education, business, and retail sales. We also see a number of library workers who enroll in school for advancement or professional development.

It appears that there has been an explosion in online course offerings in library and information science. Are there data on how many students are enrolled in distance versus residential programs? Are there some master's degree programs that are a hybrid? Has ALISE or any other body sponsored research evaluating the quality of online programs?

We don't have figures that indicate the balance of enrollment in distance and residential programs that have been aggregated on the national level, nor do we have directly comparable data on those enrollments. ALISE is currently working on a project to evaluate the data elements we collect for the ALISE Statistical Report, so this is certainly an area for us to look at.

The Statistical Report does tell us that well over $80 \%$ of schools with ALA accredited master's programs offer distance education courses in a variety of formats. Web courses are the most frequently offered: nearly 1,100 sections were offered in academic year 2004-2005. On-site but off campus face-to-face courses remain popular and were the next most frequently offered, followed by hybrid or multimedia courses and video. Many programs offer a combination of on-site instruction and other delivery mechanisms. Some others have completely separate online programs. The majority of online programs, however, require some sort of intensive, on-campus experience.

There have been several research studies that explore the quality of online programs. The WISE (Web-based Information Science Education) project is a consortium of schools that works to enhance online pedagogy as well as to share courses. (See www.wiseeducation.org/home_p-home. aspx) Perhaps the most influential factor in program quality, however, is the ALA Committee on Accreditation. The ALA Standards for Accreditation require that schools meet the same standards of quality in their distance education programs as they do in their on-campus programs.

Is there a core curriculum in library and information science? If so, what does it look like? I am sure RUSQ readers would be interested in learning whether or not reference (if it is still known as that) is generally a required course.

This is an area that seems to provoke a great deal of discussion. Is there a course by course congruence among the required courses in all of the ALA accredited programs? No. Are the basic concepts outlined in the ALA Standards for Accreditation found across all of the programs? Yes. I found Renee McKinney's analysis of curricula of ALA accredited schools and the ALA Draft Core Competencies very revealing. She found that nearly $95 \%$ of the schools offered courses to address all eight of the core competencies. Ironically, for those who keep up with such concerns, a Knowledge Organization course was required in all but one of the ALA schools (and that one not yet fully accredited).

"Reference" is not mentioned in the ALA core competencies, but it seems to fall under "Knowledge Dissemination: Service." According to McKinney's analysis, nearly $75 \%$ of the programs offer a required course in this area.

In my quick review of curricula of ALA accredited programs, the majority of programs (34) have a "reference" course as a core requirement and another few include the course as a guided (or second tier) elective. That is, reference is one of a second level of required courses. Another eight offer such a course as an elective. I defined a reference course as one that, regardless of its title, included the components of a basic reference course: exploration of users and user needs, interpersonal interaction and question analysis, and information resources and retrieval processes. By far the most frequently used course title is some iteration of "information sources and services." Variations of "reference and information services" or just plain "reference" are still used in many schools. I cannot estimate how many students and faculty use "reference" as shorthand for more elaborately titled courses, but I think the practice is fairly widespread.

In the Fall 2007 issue of RUSQ Lisa O'Connor contributed an interesting editorial on the tension between theory and practice in library education (see "Nice Shoes"). She makes a case for a clinical model of library education. Do you have any suggestions for how library school educators can keep up with changes in the profession to better prepare students? Does ALISE programming or committee work connect educators with practitioners?

I certainly felt a great deal of kinship with Lisa when I read her article, and agree with many of her ideas and observations. (Who could not love an editorial entitled "Nice Shoes"?) I'm not quite sure I agree with the premise embedded in this question, which is that LIS educators lag behind practice. I actually see a synergistic situation in which interaction between educators and librarians keeps the field moving forward. That is, I'm not sure that practice drives education or education drives practice, simply that working together, we advance together. As Lisa laments, it seems unlikely that we will find the resources to develop a fully 


\section{FROM THE EDITOR}

articulated clinical model for LIS education, even if such a model were appropriate.

Effective faculty fulfill their research, teaching, and service responsibilities and develop meaningful pedagogy by interacting with librarians. Faculty keep in touch with practice by reading the literature; most faculty are involved in association activities. I could point to the many activities in professional associations in which LIS educators are engaged and identify theory and model development that supports practice. It is not the role of faculty to work in libraries, but to understand what goes on there and to offer a broader context, richer perspective and deeper understanding of those practices. It is dangerous to name individuals, but Marie Radford, Joan Durrance, Melissa Gross, and Catherine Ross all come immediately to mind as examples of educators whose work reflects current awareness, a scholarly perspective, and immediate applicability.

ALISE fosters this interaction of practice and education and promotes conversation in a number of ways. The annual conference is always linked to the ALA Midwinter Meeting providing the opportunity for faculty to move conveniently from one meeting to the next. The conference program reserves space for programming by the ALA Committee on Accreditation. The Association provides guidelines and procedures for field experiences and internships. The Adjunct and Part-Time Faculty Special Interest Group is a longstanding group within the organization. In recognition of the growing number of adjunct and part-time faculty who teach in our programs (approaching 40\%), ALISE has recently undertaken a project that focuses on these valuable contributors and ways to more fully integrate them into the educational endeavor. The ALISE annual conference program for several years has stressed the integration of practice and scholarship to produce reflective practitioners; this year's theme is "Community Engagement: Integrating Learning, Research, and Practice."

There is a concern about the graying of the library profession, especially given the substantial number of librarians who will be reaching retiring age in the next decade. Is this also a concern for library schools? If so, who will be teaching library school students in future years?

Of course there's concern-and it's immediate. We are concerned not only about replacing ourselves in the future, but in expanding our faculties now in anticipation of the need for the next generation of librarians. Recruiting new students is a high priority in all of our Ph.D. granting programs. Since 2003, the IMLS has funded over 175 doctoral students. Doctoral programs continue to be a significant category of funding in FY2008, with a call for proposals designed to develop faculty to educate the next generation of library professionals and library leaders. I'd especially like to point out that the focus of these grants is on educating those who will work in school, public, and academic libraries. As to who will be teaching students in MLIS programs in the future, we'll probably see a sizable number of adjunct and part-time instructors. I expect that some of these will be library professionals who have Ph.D.s and are interested in keeping active in the field after retirement. Many faculty work well into their seventies, so we'll see many of the same faces for the next decade. Of course, we have very talented junior faculty who will move through the ranks. I see absolutely terrific students in our doctoral programs, but too few of them. You know, Diane, you'd be great, so if you're thinking about a career in library education...

One of RUSA's initiatives has been to recruit student members. Does ALISE encourage members to promote the importance of service in professional organizations?

Hmm . . . No, I don't think I can point to a specific ALISE program or initiative that encourages members to promote the importance of service in professional organizations, although service learning will be one of the areas explored as part of our 2008 community engagement conference theme. As the ALISE president, I had the enjoyable experience of meeting with the ALA-affiliates group. I was thrilled by the work all of these associations and how their members contribute to the profession. It's been my privilege during this past year to work with ALISE members who are generous and dedicated in their support of library and information science education.

It may sound a bit naive, but I think that the value of service is a given in our profession. I think the most important aspect of teaching in a professional program is acting as a role model and mentor, and it is always a joy for me to see my colleagues at conference and realize the quality of models available to our students.

Thank you for the opportunity to talk with you, Diane. It seems like old times to be working on a RUSQ editorial! 